Stanisław Otok

\title{
NATURE OF SOCIAL LANDSCAPE
}

According to the widespread idea, landscape is usually understood as external outlook of an area in which one actually is or with which one's aesthetical, often subjective, emotions are connected; another such common idea ascribes this name to paintings representing this or another locality. In both these cases adequate adjectives are applied in order to more precisely define the type of landscape meant: mountainous, plain, forest or desert, etc.

In scientific terms, though, landscape is defined in many ways, differing by the scope encompassed or emphasis placed upon various features considered in the definition. Most often landscape is understood as the set of features of a certain area, in which these features constitute a synthesis of both natural and anthropogenic elements. Similar definition can be found in an encyclopaedia: "Landscape, physiognomy of the Earth's surface or of its part, being the synthesis of all natural elements and human activity, remaining in' natural relation and interaction" (Wielka Enyklopedia Powszechna, PWN, vol. 6, p. 137). It is to this type of definition that the author of this paper is inclined, intending to encompass in this notion also the definition of social landscape, understood as the set of natural and social features of a certain area.

Historical development of semantic contents of the world "landscape" was highlighted by R. E. Dickinson (1939) and J. Schmithüsen (1978). According to these authors, until the 15 th century one is encountering the notion of landscape mainly in the meaning of an area, territory, region or neighbourhood, or a contiguous area of lands. With the development of landscape painting, when paintings included a background meant to characterize the area or region in which persons or actions were presented, the notion acquires a new significance. Since many other words corresponded to the notion of "area", the main meaning of the notion "landscape" was transformed to indicate a segment of geographical space or a set of objects characteristic of a given locality. Its physiognomy was presented. Certain reality was understood under this notion. With time, the term "landscape" passed from the domain of painting also to that of literature, 
and later, in the 19th century, became a commonly used term for the notion of the "set of features of a locality", created by A. Humboldt.

In the further course of development of the notion of landscape the following approaches can at least be distinguished: (a) German, (b) French, (c) American, (d) Russian and (e) Polish.

(a) German approach. In the second half of the 19th century, a holistic understanding of landscape disappears, and, instead, elementary constituents of landscape take the first place in its perception. Thus, where A. Humboldt (1808) saw the "set of features of a locality", K. Ritter (1822) wrote about the pattern specific for a given country or land, and F. Richthofen (1883) already only about an agglomeration of elements of nature. At the end of the 19th century, though, there is a come-back to systemi: or holistic studies. This change is due to O. Schlüter (1928), who, displeased with the anthropogeographic approach represented by its founders, suggested in his concept of cultural landscape morphology that geography of man should help in recognition of forms and distribution of terrestrial phenomena in so far as this is allowed by perception by senses. According to Schlüter, a small region is a landscape or a physiognomic unit in which all perceivable phenomena, both natural and anthropogenic, having spatial features, form together distinct assemblies. This concept was being developed further, with certain modifications, by S. Passarge (1933) and A. Penck (1928), while N. Krebs (1923) added that in order to understand landscape and spatial connections of its elements it is essential to study the social structure and features of a society which created it and lives in it. E. Neef (1967), on the other hand, thinks that the notion of landscape does not denote an individual regional unit, but rather the essence of geographical reality characterized by enormous spatial differentiation.

(b) French approach. In this case, landscape is introduced to geographical vocabulary as aspect, physiognomie, paysage, with each of these terms applying equally to urban and rural areas. The pioneering work in morphology of cultural landscape was performed by J. Brunhes (1910) inspired by $\mathbf{P}$. Vidal de la Blache. The concept of studies conducted by J. Brunhes was based upon visible and tangible, i.e. upon evident traces of human activity on the Earth's surface. This approach developed into the well-known French regional school.

(c) American approach was initiated by C. O. Sauer (1925). In accordance with the assumptions given by the author in his book The Morphology of Landscape, a landscape is an area composed of distinct, naturally linked forms, both physical and cultural. Its structure and functions are determined by integrally dependent forms. The task of geography is to grasp the content, individuality and relations of area in which man comes into due attention as part of the area, but only in so far as he is really significant through his presence and work. Sauer's concept of 
landscape morphology indicates convergence with the concepts of German geographers working in the same domain, and mainly of A. Hettner, S. Passarge and N. Krebs. Sauer did, anyway, carry the ideas of the school of thought inspired primarily with that respect by German geographers. Landscape problems of social significance are being considered presently primarily by American architects and town planners.

(d) Russian and Soviet approach. Partly independently of the development of geography in Germany the science of natural complexes took shape in Russia, and thereafter in the USSR. From among many geographers, L. Berg (1913) deserves special attention. His opinions were for a long time a basis for the development of landscape theory. Berg was using this notion both. in typological and in regional meaning. In later period, field studies of landscapes were initiated on a greater scale in the Soviet Union. Within that current N. Solntsev (1943) proposed the idea that every individual landscape, in a regional sense, is composed of smaller, repetitive units, called by him morphological constituents of landscape. D. Armand (1975) conducted practical landscape studies with the assumption that regionalization depends upon the goal it should serve and is therefore always of subjective character, and that comprehensive landscape regionalization should not be identified only with physico-geographic regionalization.

Landscape is for Armand synonymous with territorial complex. Armand founded the science of natural landscape based upon the theories of natural sciences.

(e) Polish approach. The beginnings of interest in landscape are connected with the activity of such geographers as W. Pol (1851), A. Rehman (1895) and W. Nalkowski (1914), who were influenced by A. Humboldt and K. Ritter. A. description of Polish landscapes understood as physiognomic types of territory was provided by J. Smoleński (1912). During World War I S. Pawłowski (1917) and, independently, S. Srokowski (1918) gave in their publications an original landscape presentation of Poland. On the other hand, S. Lencewicz (1958), a geographer from the period between the two world wars, when presenting his view on problems of regionalization and landscape distrimination, distinguished these two questions and thought that landscape was merely a physiognomic feature based upon the external outlook and that it did not reflect the whole of geographical features determining the individuality of an area. This problem was taken up after World War II by J. Kondracki ((1976), R. Galon (1955), T. Bartkowski (1979) and others with respect to studies on landscape typology and urban physiography. In recent years, studies of Polish landscape were taken up also by architects and town planners. Among the latter ones J. Bogdanowski (1985) and B. Zaufal (1973) were contributing to the diffustion of physiognomic and aesthetical concept of landscape studies. 
All the presented approaches to the definition of landscape do in fact display a general agreement as to the fact that landscape is a spatial unit determined by a set of natural and anthropogenic features, to be considered in appropriate research. Thus defined landscape is a system in which one is dealing with functional elements coming from two spheres of factors, i.e. from nature and human activity. Degree of integration of these two spheres of factors is simultaneously the basic feature of landscape types. It is understood this was also the case in sociology and social geography, where it appears under the term of social space.

Are "space" and "landscape" equivalent notions? According to H. Langer (1970), they can be taken equivalent as to their essence solely as goal-oriented notions. In the same sense space and landscape, used equivalently, denote the area where human society dwell or live. As the valourizing notions, they characterize the setting of spatial relations having existential significance for the society, i.e. certain open dynamic system with definite functional capacity from the point of view of this society.

The notion of social space was introduced by E. Durkheim. He saw social differentiation from strictly social viewpoint. According to Durkheim (1893), sociology is composed of social morphology, which is devoted to studying social bases (the setting of social forms), and social psychology, which consists of studying the influence exerted by the community and culture on psychological phenomena, and of the analysis of psychological mechanisms appearing in the life of society. In the eyes of E. Durkheim social basis is constituted by the mass of individuals forming the society, the way of their distribution on the Earth, as well as character and pattern of all kinds of things which influence collective relations. Constitution of the basis does directly or indirectly influence all social phenomena, similarly as psychological phenomena remain in indirect or direct relation to the state of the individual's brain.

M. Sorre (1957) has reached the conclusion that the "social basis" should combine the notion of physical and social environment and he applied Durkheim's term of "social space" to thus understood social basis. Sorre saw the social space in general scale as a mosaic area composed of homogeneous subspaces, where homogeneity is understood in terms of spatial perceptions of subspace inhabitants. Each social group has its own distinct space which reflects its particular values, preferences and drives. These are homogeneous or simple spaces, to which I shall return in the further course of the paper. Sorre maintained that every lifes style inscribes itself in a typical environmental form. In the case of rural environment, it indicates how the work rhythm, the setting of agricultural conditions, the social structure and economic activity are related to housing types and village patterns. Sorre was writing in more detail about the "ecology of rural fife", and about harmony linking local community, economy and geographical environment into one compact 
whole, which finds its reflection in the forms of environment of a region.

In the urban context, though, ecological formulations concerning the social space of Sorre showed certain gaps in the functional domain. These gaps were in a certain sense bridged by $P$. Chombart de Lauwe (1962) for whom urban space meant a hierarchy of spaces within which groups live, move about and mutually influence each other. Starting with the assumption that each group has its own space, Chombart de Lauve calculated the theresholds in social space, which should not be transgressed by particular social groups if these groups are not to risk disappointment, stress and impression of anonymity. The same author concluded also the studies of dimensions of social spaces working hard on the answer to the question of actual surface, in square meters, which schould be the per capita norm in a given space.

A. Buttimer (1969) also considered notions relative to social space and she concluded that they appeared in anthropology and social psychology under the term of biotype. In social psychology a "biotype" is defined as the environment or location which attracts the organism by certain combinations of teaching, memorization and instinct. Ecological approach to studies of such biotopes of ethnic communities is presented in the results of the research work of F. Barth (1956) and in a publication by E. Hall (1966) on the "science of the future", where a similar approach to analysis of town was applied.

Polish studies of problems related to social space were primarily conducted by sociologists and town planners. S. Rychliński (1976), when working on urban sociology, regarded town as a set of quarters concentrating various kinds of activities, or different types of residential environments; both kinds of units form the so-called "natural areas of town", which become separate depending upon who lives in a given area. This interesting problem was also taken up by B. Jałowiecki (1968) in his sociological and town planning study of residential units in Wrocław. Jałowiecki directed his study towards the problem of socio-spatial relations of an urban housing estate and town.

Transformations of social space, conceived in terms of social landscape were depicted by geographers S. Otok and A. Achmatowicz-Otok (1988). A. Reynaud (1979) thinks, however, that the notion of space, so fashionable recently, is a frequently often used, but vague term whose meaning is differently defined and/or understood in various concepts.

It should be concluded that the notions of landscape and social space, presented here, are used as heuristic terms in creation of various directions of analytical studies of spaces in terms of space perception by their inhabitants, each one being analysed rather by specialists from various disciplines than by just one branch of science. Thus, the application of the notion of social space does not solve all these problems which a geographer would like to take up in the studies of 
environment and society. Under these circumstances, I propose to consider the possibility of introducing a new, comprehensive in nature, framework name, concerning studies on motivation of human behaviour in space.

Assuming that every social group has its own clearly defined space, reflecting its values, preferences and goals, one should adopt a name which would imply comlementarity of various unitary social spaces in a comprehensive perspective. This name must account for the ability of complementing each other and, at the same time, it must determine the degree of mutual interaction among groups, while accounting also for natural conditions in which these conditions appear.

Such a comprehensive and complementary social space with definite natural conditions will be called social landscape. The definition of this term is as follows: social landscape is an area over which the set of features constituting the synthesis of natural and social elements remain in relationship and influence each other. Thus understood social landscape is also a system.

\section{REFERENCES}

In view of limited space of this publication only these titles are given which represent publications characterizing the problem undertaken in the paper against the background of world achievements.

A r mand, D., 1980: Nauka o krajobrazie (Science of landscape; in Polish, translated from Russian by J. Kondracki), PWN, Warszawa.

C h m a 1, H., 1976: „Ochrona krajobrazu jako przedmiot planowania przestrzennego i badań naukowych" (Landscape protection as the subject of spatial planning and scientific inquiry), in: Pietrucha, J., (ed.): Spoleczne cele ochrony środowiska, SIN, Katowice, pp. $138-171$.

Dick in s o n, R. E., 1939: "Landscape and society", The Scottish Geographical Magazine, 55, 1 , pp. $1-15$.

K ond r a cki, J., 1976: Podstawy regionalizacji fizyczno-geograficznej (Foundations of physico-geographical regionalization), PWN, Warszawa.

L a n g er, H., 1970: „Landschaftsökologie und Raumplanung”, in: Prace a materialy $z$ biologie krainy, 14, Bratislava, pp. 1-29.

Ot ok, S., 1987: Geografia spoleczna (Social geography). PWN. Warszawa.

Otok, S. A ch mat ow icz-O tok, A., 1988: "Social aspects of transformation in the physiognomy of buildings", in: Otok, S. (ed.): Research approach to social geography, Warszawa.

R e y $\mathrm{n}$ a ud, A., 1979: „Le concept de classe socio-spatiale. La notion de „region” dans son contexte social", Travaux de l'Institut de "Géographie de Reims, 38.

S ch m it h ü s e n, J., 1970: „Begriff und Inhaltsbestimmung der Landschaft als Forschungsobject vom geographischen und biologischen Standpunkt", in: Questiones geobiologicae, 7. Slovenska Akad. Vied, Bratislava, pp. 13-25. 